and placebo (3 times daily), for 3 months. Anti-ds DNA serum levels were measured by ELISA and urine protein were measured by urine albumin creatinine ratio (UACR).

Results After supplementation for 3 months, this study showed that decreased of anti-dsDNA serum levels in the supplementation group was significantly greater than in the placebo group. The decreased of UACR in the supplementation group was also significantly greater than the placebo group.

Conclusions Adding curcumin on vitamin D supplementation can decrease anti-dsDNA serum levels and proteinuria greater than vitamin D supplementation plus placebo in SLE patients with hipovitamin D.

\section{THE EFFECT OF ADDING CURCUMIN ON VITAMIN D3 SUPPLEMENTATION ON CYTOKINES BALANCE, IN SLE PATIENTS WITH HYPOVITAMIN D}

${ }^{1} \mathrm{CS}$ Wahono*, ${ }^{1}$ S Saveria, ${ }^{1} \mathrm{CD}$ Setyorini, ${ }^{1} \mathrm{ZD}$ Wahyuni, ${ }^{2} \mathrm{~K}$ Handono, ${ }^{1} \mathrm{H}$ Kalim. ${ }^{1}$ Universitas Brawijaya/Saiful Anwar Hospital, Internal Medicine, Malang, Indonesia; ${ }^{2}$ Universitas Brawijaya/Saiful Anwar Hospital, Clinical Pathology, Malang, Indonesia

\subsection{6/lupus-2017-000215.258}

Background and aims Vitamin D has important roles in the regulation of the immune system in Lupus. Seventy percent of lupus patients in Indonesia are experienced hypovitamin D. Curcumin is a natural VDR ligand and has sinergic effect with vitamin $\mathrm{D}$. This study was aimed to determine the effect of adding curcumin on vitamin D supplementation on IFN- $\gamma$ / IL-4 ratio and IL-17/TGF- $\beta$ ratio, in SLE patients with hipovitamin D.

Methods This was a randomised controlled trial, double blind study. Forty SLE patients with hypovitamin D were studied, that randomised into two groups: 20 patients (supplementation group) received vitamin D (cholecalciferol 1200 IU daily) with curcumin $20 \mathrm{mg}$ (three times daily); and 20 patients (placebo group) was given vitamin D (cholecalciferol 1200 IU daily) and placebo ( 3 times daily), for 3 months. Cytokines serum levels (IFN- $\gamma$, IL-4, IL-17, TGF- $\beta$,) were measured by ELISA.

Results After supplementation for 3 months, this study showed that decreased of IFN- $\gamma / \mathrm{IL}-4$ ratio in the supplementation group was significantly greater than in the placebo group. The decreased of IL-17/TGF- $\beta$ ratio in the supplementation group was also significantly greater than the placebo group.

Conclusions Adding curcumin on vitamin D supplementation can decrease IFN- $\gamma / \mathrm{IL}-4$ ratio and IL-17/TGF- $\beta$ ratio than vitamin D supplementation plus placebo in SLE patients with hipovitamin D.

\section{THE EFFECT OF VITAMIN D3 SUPPLEMENTATION ON THE ANTI-DSDNA LEVELS AND URINE PROTEIN IN SLE PATIENTS WITH HYPOVITAMIN D}

${ }^{1} \mathrm{H}$ Susianti* ${ }^{2}{ }^{2} \mathrm{CS}$ Wahono, ${ }^{2} \mathrm{ST}$ Priyantoro, ${ }^{1} \mathrm{~K}$ Handono, ${ }^{2} \mathrm{H}$ Kalim. ${ }^{1}$ Faculty of Medicine Brawijaya University/Dr. Saiful Anwar General Hospital, Clinical Pathology, Malang, Indonesia; ${ }^{2}$ Faculty of Medicine Brawijaya University/Dr. Saiful Anwar General Hospital, Internal Medicine, Malang, Indonesia

\subsection{6/lupus-2017-000215.259}

Background and aims Vitamin D has important role in the regulation of the immune system in Lupus. $71 \%$ of lupus patients in Indonesia experienced hypovitamin D. This study was aimed to determine the effect of vitamin D supplementation on the levels of anti ds dna and degree of urine protein in lupus patients with hypovitamin D.

Methods Thirty nine SLE patients with hypovitamin D were studied, that randomzed into two groups: 20 patients was given vitamin D and 19 patients received placebo for 3 months. Anti-ds DNA levels were measured by ELISA and urine protein were measured by dipstick method.

Results Anti-dsDNA levels in the supplement group before and after giving vitamin D were $226.84 \pm 82.11$ vs $191 \pm 72.55$ $(p=0.00)$, and the placebo group were $233.69 \pm 66.52$ vs $227.72 \pm 61.21(p=0.077)$. The degrees of urine protein in the supplement group before and after treatment were 24 vs $12 \mathrm{U} / \mathrm{ml}(\mathrm{p}=0.003)$ and the placebo group were 16 vs $10 \mathrm{U} /$ $\mathrm{ml}(\mathrm{p}=0.070)$.

Conclusions Vitamin D supplementation plays a role on decreasing the levels of anti ds-DNA and urine protein in SLE patients with hypovitamin D.

\section{THE EFFECT OF VITAMIN D3 SUPPLEMENTATION ON THE DISEASE ACTIVITIES AND DEGREE OF FATIQUE IN SLE PATIENTS WITH HYPOVITAMIN D}

${ }^{1} \mathrm{CS}$ Wahono*${ }^{2}{ }^{2} \mathrm{H}$ Susianti, ${ }^{1} \mathrm{~A}$ Rifai, ${ }^{2} \mathrm{~K}$ Handono, ${ }^{1} \mathrm{H}$ Kalim. ${ }^{1}$ Faculty of Medicine Brawijaya University/Dr. Saiful Anwar General Hospital, Internal Medicine, Malang, Indonesia; ${ }^{2}$ Faculty of Medicine Brawijaya University/Dr. Saiful Anwar General Hospital, Clinical Pathology, Malang, Indonesia

\subsection{6/lupus-2017-000215.260}

Background and aims Vitamin D has important roles in the regulation of the immune system in Lupus. $71 \%$ of lupus patients experienced hypovitamin D in Indonesia,. This study was aimed to determine the effect of vitamin D supplementation on the degree of disease activity and degree of fatigue in SLE patients with hypovitamin D.

Methods Thirty nine SLE patients with hypovitamin D were studied, that randomised into two groups: 20 patients was given vitamin D and 19 patients received placebo for 3 months. Disease activity is determined by the SLEDAI scores and the degree of fatigue is determined by the FSS (Fatigue Severity Scale).

Results This study showed that supplementation of vitamin D $1200 \mathrm{IU}$ per day increased 6:55 $\pm 1: 27 \mathrm{ng} / \mathrm{cc}$ of $25(\mathrm{OH}) \mathrm{D}$. The decreased of SLEDAI scores in the supplementation group were greater than the placebo group $(6.45 \pm 3: 07$ vs 0.17 $\pm 1.63), p=0.000$. The decreased of Fatigue Severity Scale in the supplementation group also greater than the placebo group $(2.27 \pm 0.73$ vs $0.005 \pm 0.62$.), $\mathrm{p}=0.000$.

Conclusions Vitamin D supplementation plays a role on improving the activity of the disease (SLEDAI score) and the condition of fatigue (FSS) in SLE patients with hypovitamin D.

\section{LONG-TERM EFFECTS OF OF HYDROXYCHLOROQUINE ON METABOLISM OF SERUM LIPIDS AND LEFT VENTRICULAR STRUCTURE AND FUCTION IN PATIENTS OF SYSTEMIC LUPUS ERYTHEMATOSUS}

1J Meng. 'Beijing Chao-Yang Hospital- Capital Medical University, Department of Rheumatology and Immunology, Bei Jing, China

10.1136/lupus-2017-000215.261 